\title{
A new systematic approach in new product development through an integration of general morphological analysis and IPA
}

\author{
Mehdi Sholeh $^{a}$, Ahmadreza Ghasemi ${ }^{\text {* }}$ and Meisam Shahbazi ${ }^{\text {b }}$ \\ ${ }^{a}$ MA. Department of Industrial Management, Faculty of Management and Accounting College of Farabi, University of Tehran, Qom, Iran \\ ${ }^{b}$ Assisstant Professor, Department of Industrial Management, Faculty of Management and Accounting College of Farabi, University of Tehran, Qom,
} Iran

\section{H R O N I C L E}

Article history:

Received January 16, 2017

Received in revised format:

May 22, 2017

Accepted May 28, 2017

Available online

May 28, 2017

Keywords:

New Product Development

Morphological Analysis

Critical Success Factors

\begin{abstract}
A B S T R A C T
New product development is a modern approach to deal with the environmental changes and an introduction to enter the competitive atmosphere is a challenging condition. By realizing the critical aspects of success of the new product and selecting a compatible model of variables in these aspects, companies may create a unique context for developing the product; but whether in terms of the multiplicity of the decision-making choices or the inherent conflicts of the response atmosphere's variables, the complexities of the current world have caused disruption and inefficiency in the field of optimal selection and decision making. The aim of this study is to identify the critical aspects of development of the new product in the Sedan automobile class and to offer a morphological model of that by investigating the ideas and comments of the experts and scholars. In this regard, by using the Importance-Performance Analysis (IPA) method, the proposed method assesses the mode of the organization; and with the General Morphological Analysis, it assesses and searches for the most compatible decisionmaking variables to find the fully optimal and compatible solutions. After studying the subject literature, seven critical aspects are selected for the product development and three purposes are chosen for limiting the morphological model. Finally, four fully compatible configurations and one configuration are proposed with the entrance of the aspects determined from the output of IPA method. The innovative solution in solving the morphological model and its integration with IPA method are considered as the innovations of this study.
\end{abstract}

(C) 2018 Growing Science Ltd. All rights reserved.

\section{Introduction}

Most pioneer companies all over the world are completely aware of the fact that the most important factor causing their success and preferences in the global competition market is to have the ability to continue designing the new products for the market faster and most effective than the other competitors. Development of new product and improvement of the current product play essential role for most

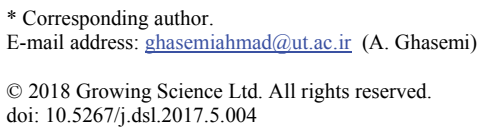


successful producers. New product development is a very important process to guarantee the company's survival because of the welfare and the development of the national economy of the countries. Multiple aspects of the issues in the current era create useless and destructive conflicts in the new product development process. As a result, all producer seek for the development of patterns and methods, which help them minimize the failure risks of such projects and increase diversity in products.

Development and introduction of a new product is from the most important strategic decisions, which can be made (Cooper, 1999). However, achieving the development of new successful products is not easy and a few percent of the new products brands are successful (Marzler \& Hinterhuber, 1998). Today, there is a worldwide competition among different companies in terms of new product development. This competition is based on tens of thousands of business activities and includes a wide range of activities such as market research, product development, production process and the products services. Regarding to the high cost of these projects for their organizations, when developing new products, a deep understanding of the needs and expectations of the customers, techniques, and the knowledge of developing new products is required to achieve the business purposes (Lagrosen, 2005).

From the strategic viewpoint, the new product development process must positively answer the customers' expectations and create an appropriate competitive field for the organizations by relying on the preference of technology and suitable allocated budget (Smith et al., 2004). If we plan to reach a comprehensive perception about the new product development process, we have to do it in its best way. However, what is clear is that the process of new product development has a multi-aspect nature that should be identified and modeled in order to propose its desired system.

Basically, administrating a prescription for all companies is not possible, because the nature of companies, their strategies, and the most importantly, the types of products and goods are the factors, which increase the complexity of the issues. The general pattern of new product development is from the creation of idea to delivering it to the customer. This general pattern passes different stages during the new product development and they are sometimes in the form of filter or feeding lines and in fact bring the products to the evolution stage; hence, the process of new product development includes all processes related to strategy, organizing, concept creation, creating and assessing the product, creating and assessing the marketing and commercialization plan of a new product (Chen, 2012).

This study is intended to propose an integrated model in automobile industry in order for us to have a successful new product development process.

\section{Literature Review}

Here we investigate the literature of the new product and the critical aspects in success. In 1990, Copper compared the successful and unsuccessful companies in production and product development through regular studies and investigated the factors influencing the acceleration of the new product's success during 20 years for 100 durable products in 35 companies in Europe and the Northern America and the chemicals' producers. He showed that the marketing factors (customer need, production time, profit, market share, economic effect on the customer, and creating value for the customer), technology (technology's success, technology's value, and reduction of cost) and the commercializing factor with indices of the company specification, competitiveness of the product, and the efficiency of the product management team had been respectively from the important indices in NPD process in the companies. Sarmad Saeidi and Mamqani (2009) studied the key factors of success in new product development in Saipa Automotive Group through the hierarchical analysis approach. They investigated factors such as team, motivation, idea screening, and monitoring competitors, knowledge, decision-making risk in management, using consultants out of the company, the staffs' and the project team's competency, motivation, commercialization, etc. They examined four technologic, marketing, new product team, and commercialization. 
Yoon and Park (2005) carried out a factor analysis for factors influencing on technology, research, and development and finding solutions using the morphologic analysis. They reported that through using the morphologic analysis, it is possible to reduce the number and filtering the technological options.

By investigating the critical factors in new product development from the viewpoints of industry managers in 74 Chinese industrial companies, Mu et al. (2007) showed that four technological, marketing, managerial, and commercializing factors were critical and significant for the new product decision-making in all industries in the successful decision-making for producing new product. In 2008, they also investigated the impact of the risk management strategy on the performance of new product which was the result of examining 217 manufacturing companies in China. They showed that the risks existed in technological, marketing, and managerial risks and the integration of three factors with each other maintained a positive impact on the performance of the new product development.

With the paper of systematic approach for developing a new business model in a telecommunication company and using the morphologic analysis and fuzzy integrated approach, Im and Cho (2013) quantified the output of the morphologic analysis. Their two-step proposed method included the identification of a set of all possible combinations of business model with morphological analysis; and in the second step of assessment, it included ranking and selecting by means of the Fuzzy Analytical Hierarchy Process (FAHP) and TOPSIS solution.

\section{Soft Research Methodology}

Soft operational research includes a set of methods and methodologies that based on the different perceptions of the benefactors, adjust the required structure for the bad-defined, chaotic, and unstructured problems. In other words, it can be said that soft operations research is the methodology set of "problem structuring methods (PSM)". From these methods, we can refer to the soft systems methodology, cognitive mapping, analysis and development of strategic options, strategic option approach, stability analysis and structural and perceptional modeling (Azar et al., 2013), and morphology (Ritchey, 2011). In this multiple paradigm, there are multiple methodologies like network analysis, DEMATEL, and importance-performance analysis methodologies (Azar et al., 2013).

\subsection{IPA Method}

Importance-performance analysis was first introduced by Martila and James (1977) for analyzing the performance of car industry. This approach provides an insight for the managers to identify the strength and weakness of the organization. IPA simultaneously identifies the most important influencing factors on the customer's satisfaction as well as the low performance features of the organization that should be immediately improved and contributes to the managers to provide better services (Azar et al., 2013). The traditional approach is structured to the importance-performance by the two-dimensional matrix. This matrix consists of two axes where $\mathrm{X}$-axes shows the performance and $\mathrm{Y}$-axes indicates the importance. As it is shown in the Fig. 1, this matrix is divided into four quadrants.

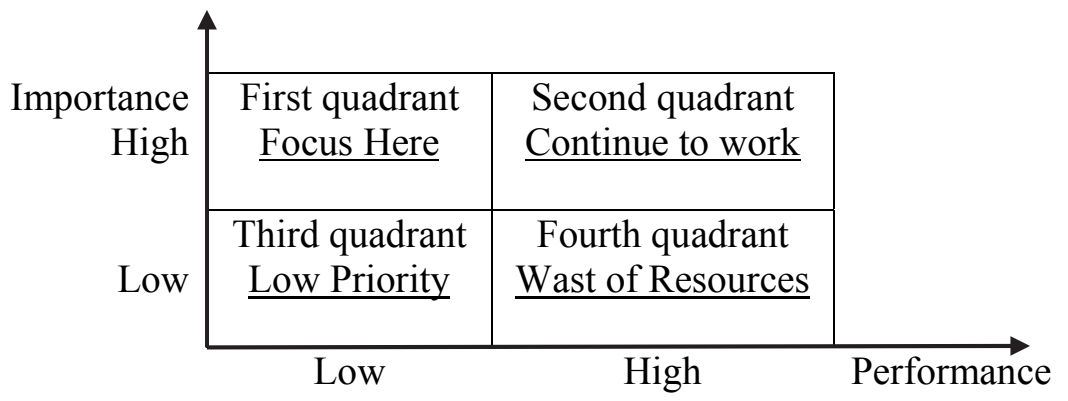

Fig. 1. importance-performance matrix (Azar et al., 2013) 
1. The first quadrant (focus here): the perceived features are very important for the respondents, but the performance level is relatively low. This quadrant shows the fundamental weakness of the organization; hence, it requires immediate attention for being improved.

2. The second quadrant (continue the work, well): the perceived features are very important for the respondents, meanwhile, the performance of the company in these activities is at its highest level; hence, under this condition, the work should be well maintained and kept on.

3. The third quadrant (low priority): the perceived feature in this quadrant is assessed low in terms of performance and importance. However, here the performance level is low, but the managers should not pay so much attention to this part.

4. The fourth quadrant (waste of resources): this quadrant includes features with low importance but relatively high performance; in other words, the resources allocated to these features are more than the required values.

To do the importance-performance analysis, the following steps should be done:

The first step: identify and extract the features and aspects. This may be done by studying the subject literatures and by surveying of the experts and customers.

The second step: determine the importance degree of the aspects and the performance degree of the qualitative features of the aspects. $b_{j p}$ and $c_{j p}$ respectively represent the importance value and performance value determined for the aspect $j$ and by the decision-maker or expert $p$. This value is determined by using 5 or 7 options Likert scale.

The third step: use the geometric mean and integrate all comments of the experts. Here $b_{j}$ is the final value of the importance and $c_{j}$ is the final value of the performance of the aspect $j$ that is the result of the cumulative comment of $p$ experts.

$$
\begin{aligned}
& c_{\mathrm{j}}=\left(\prod_{\mathrm{i}=1}^{\mathrm{n}} \mathrm{c}_{\mathrm{jp}}\right)^{1 / \mathrm{n}} \\
& b_{j}=\left(\prod_{i=1}^{n} b_{j p}\right)^{1 / n}
\end{aligned}
$$

Therefore, each qualitative aspect $(j)$ has an importance degree and a performance degree.

The fourth step: calculate the threshold value. The threshold value is used for determining the IPA matrix cells. The arithmetic mean is used to determine the threshold value. The threshold importance value and the threshold performance value are respectively shown with $\mu_{b}$ and $\mu_{c}$, respectively.

$$
\begin{aligned}
& \mu_{b}=\frac{\sum_{j=1}^{m} b_{j}}{m}, \\
& \mu_{c}=\frac{\sum_{j=1}^{m} c_{j}}{m} .
\end{aligned}
$$

The fifth step: determine the relative location of each of the qualitative features of services on IPA matrix.

The sixth step: The gap between the importance value and performance vale of the feature $j$ multiplied by its importance value can show the weight of the qualitative aspect. The weight of the $j$ feature is shown by $O W_{j}$.

$$
O W_{j}=\left|\left(b_{j}-c_{j}\right) \times b_{j}\right|
$$


For more ease in analyzing, we normalize that as following:

$$
s w_{j}=\frac{o w_{j}}{\sum_{j=1}^{m} o w_{j}} 1, \quad \sum_{j=1}^{m} s w_{j}=1 .
$$

The aspects with higher $s w_{j}$ should be located in higher priority to be paid attention to.

\subsection{General Morphological Analysis Method}

Morphology originates in the Greek word Morph, which means the study of shapes and forms. The morphology analysis concentrates on the structure and combination of a part of the subject and how they are combined to create a concentrated whole.

The asked subject may be a physical or social. We may name typology as one of the simplest discussions of morphology that is based on the possible combinations between the two variables; so that each of the variables includes two values or modes. In the typology, each possible combination of value-variable is called a structure. The simplest and yet the most common type of typology is a four part table that has two variables against each other (Ritchey, 2011).

The morphological analysis steps are as follows, (Ritchey, 1998):

1. Determining the parameters and problem aspects: the morphology problem solving starts with identifying and determining the aspects of the problem that we want to investigate.

2. Determining different possible modes for each aspect or parameter: in this step, a range of values or different modes is allocated to each aspect or parameter.

3. Configuring the morphological context: by placing parameters against each other in a table, the ndimensional morphological filed is formed. The number of morphological aspects depends on the number of parameters obtained from the problem. A combination includes a value or mode of each of the parameters and it proposes a solution for the multiple-dimensional complex problems. Each of the combinations is called a field configuration.

5. Cross-consistency assessment (CCA): the next step in morphology is to reduce and to eliminate the possible arrangements of configurations in the problem space to fewer numbers with internal consistency with each other. This set of arrangements with internal consistency is called "the answer space".

Cross-consistency assessment is based on the approach that many pairs of modes for different aspects may be in contradiction or conflict with each other. When two modes are in endless contradiction with each other, all configurations of these two modes are incompatible and should be removed.

To assess the cross efficiency, all modes in the morphological field in a pair comparison matrix are compared with each other and their compatibility and incompatibility and the value of this incompatibility is determined in pair form. Three types of compatibility are considered in the morphology including:

The blank, means that there is no conflict in the nature of the two investigated concepts;

$\mathrm{X}$, experimental constraints (there are some limitations that we have experienced them among the concepts)

O, normative constraints (the enacted constraints caused by the moral, political, or other grounds)

Like the ISM method, aggregation of the experts' ideas will be based on mode of comments. 
In Fig. 2, the approach of the current study is summarily shown.

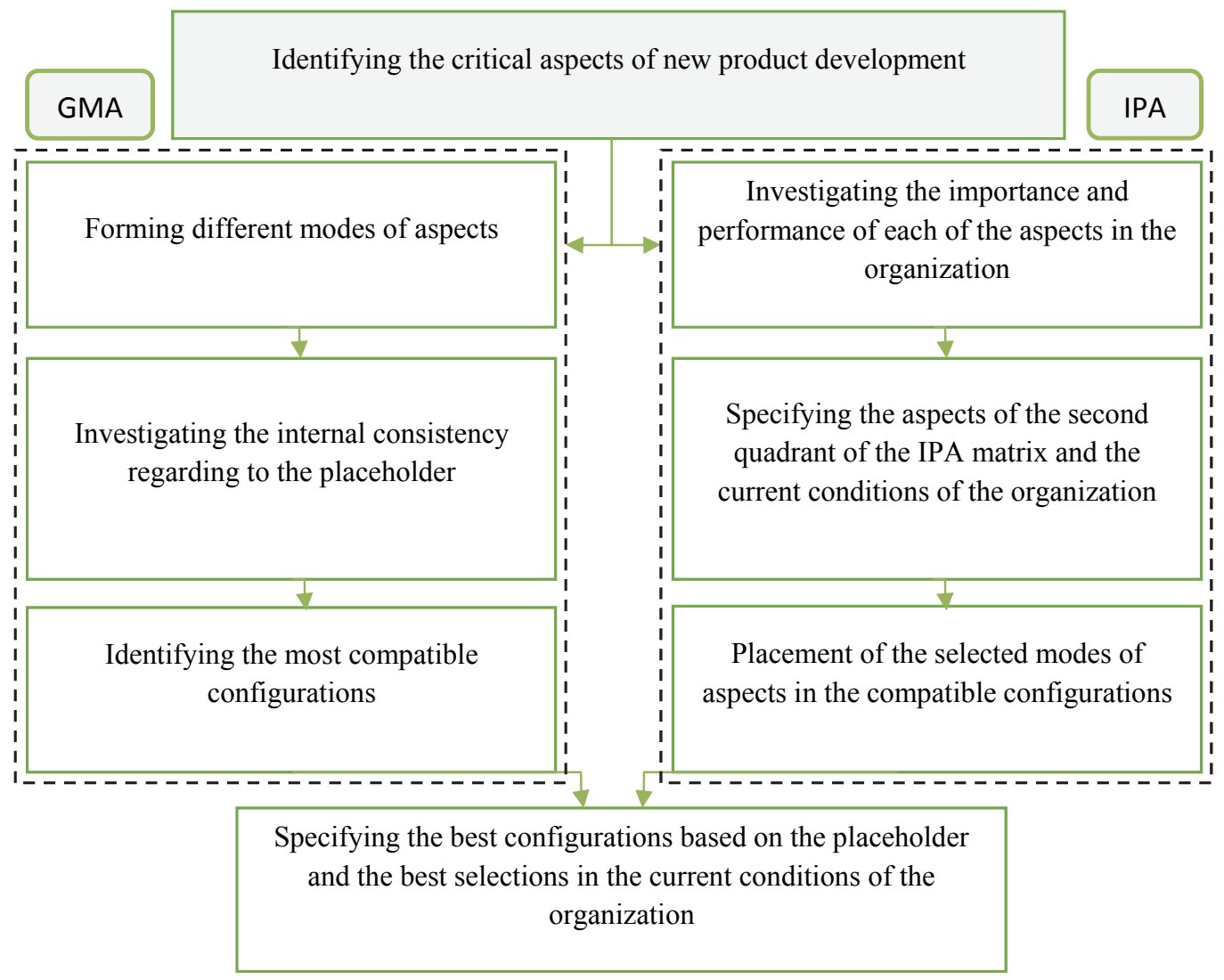

Fig. 2. The research approach

\section{Calculation Results and Assessment}

After providing the main framework and identifying the critical aspects of the success of the new product development from the review of the literature of this field, the seven aspects determined in the table have been considered for this study. In this part, using the interview and questionnaire tools and snowball sampling method and with theoretic saturation, the required information of the morphological field of this expert was gathered from the experts, scholars, and benefactors. The center of this study is Saipa Co., by having $42 \%$ of the domestic market share, which is considered as the second car producer of the country after Iran Khodro. Now, with having dozens of subsidiaries, this company is from the largest industrial manufacturers in Iran. In 1993, The Center of Research and Innovation of Saipa Automotive Industry was established with the direct investment of Iranian car manufacturing company Saipa and then, it was officially put into operation in 1997 with building the administrative, workshop, and library spaces as well as purchasing and installation of the required hardware and software equipment. Now, this company has the development of three platforms S100, S200, and S300 in its agenda.

After concluding the frequent debates, in the first step of morphological method, the critical aspects of success have been identified and they are summarily shown in the Table 1. 
Table 1

The critical aspects of success of new product development

\begin{tabular}{ll}
\hline Aspect & \multicolumn{1}{c}{ Reference } \\
\hline Project Management & $\begin{array}{l}\text { Poolton \& Barclay, 1998; Maidique \& Zirger, 1999; Cooper \& Kleinschmidt, 2007; } \\
\text { Sarmad Saeid \& Mamqani, 2009; Ardakani et al., 2011; Rajab Zade Qotri \& Moezi, } \\
\text { 2014; Rafiei Nezhad, 2014; Meygoun Pouri et al., 2014 }\end{array}$ \\
Technological and Technical & $\begin{array}{l}\text { Lester, 1998; Thompson, 2003; Seyed Hoseyni \& Iranban, 2004; Ali Ahamdi et al., 2009; } \\
\text { Ardakani et al., 2011; Talebi et al., 2011; Chen, 2012 }\end{array}$ \\
Mu et al., 2007; Fritz \& Schiefer, 2008; Ali Ahamdi et al., 2009; Ardakani et al., 2011; \\
Talebi et al., 2011; Chen, 2012; Kan'ani \& Meygoun Pouri, 2014 \\
Commercialization \\
$\begin{array}{l}\text { Cooper, 1990; Kandemir et al., 2006; Mu et al., 2007; Ali Ahamdi et al., 2009; Naranjo } \\
\text { Valencia et al., 2010; Ardakani et al., 2011; Talebi et al., 2011; Kan'ani \& Meygoun } \\
\text { Pouri, 2014 }\end{array}$ \\
$\begin{array}{l}\text { Sharma, 2006; Tushman, 2007; Sarmad Saeid \& Mamqani, 2009; Jafari Khanshir et al., } \\
\text { 2012; Khasm Afkan et al., 2014 }\end{array}$ \\
$\begin{array}{l}\text { Abbey and Dickson, 1983; Cooper \& Kleinschmidt, 2007; Naranjo Valencia et al., 2010; } \\
\text { Ardakani et al., 2011; Rajab Zade Qotri \& Moezi, 2014; Khasm Afkan et al., 2014 }\end{array}$ \\
\hline $\begin{array}{l}\text { Seyed Hoseyni \& Iranban, 2004; Jantunen, 2005; Kandemir et al., 2006; Khasm Afkan } \\
\text { et al., 2014 }\end{array}$ \\
\hline
\end{tabular}

\subsection{Importance-Performance Analysis}

The first step: after identifying the aspects, IPA questionnaire was prepared.

The second step: the questionnaire was provided to 14 experts and in the obtained data is observable in the Table 2 .

Table 2

The IPA questionnaires filled by the experts

\begin{tabular}{|c|c|c|c|c|c|c|c|c|c|c|c|c|c|c|c|c|}
\hline Code & Aspect & & 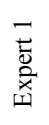 & $\begin{array}{l}\stackrel{N}{ \pm} \\
\stackrel{0}{0} \\
\text { 婳 }\end{array}$ & 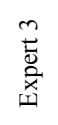 & 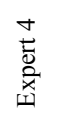 & 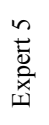 & 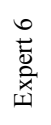 & 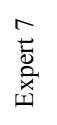 & $\begin{array}{l}\infty \\
\stackrel{\infty}{0} \\
\text { 希 } \\
\text {. }\end{array}$ & 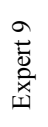 & 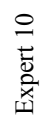 & 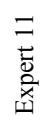 & 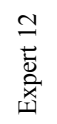 & 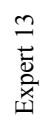 & 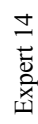 \\
\hline \multirow{2}{*}{ A } & \multirow{2}{*}{ Project Management } & importance & 5 & 5 & 5 & 5 & 5 & 7 & 3 & 4 & 6 & 5 & 5 & 7 & 7 & 3 \\
\hline & & performance & 6 & 7 & 6 & 4 & 3 & 7 & 7 & 3 & 6 & 3 & 5 & 6 & 5 & 7 \\
\hline \multirow{2}{*}{$\mathrm{B}$} & \multirow{2}{*}{ System Management } & importance & 4 & 6 & 3 & 4 & 4 & 6 & 6 & 4 & 3 & 6 & 4 & 4 & 3 & 4 \\
\hline & & performance & 2 & 3 & 1 & 4 & 1 & 5 & 3 & 3 & 1 & 4 & 2 & 5 & 3 & 1 \\
\hline \multirow{2}{*}{$\mathrm{C}$} & \multirow{2}{*}{ Technological and Technical } & importance & 5 & 3 & 6 & 6 & 5 & 3 & 7 & 6 & 7 & 7 & 4 & 5 & 4 & 5 \\
\hline & & performance & 6 & 3 & 5 & 4 & 3 & 5 & 5 & 3 & 4 & 5 & 3 & 2 & 6 & 3 \\
\hline \multirow{2}{*}{$\mathrm{D}$} & \multirow{2}{*}{ Commercialization } & importance & 3 & 4 & 7 & 4 & 5 & 7 & 6 & 3 & 7 & 5 & 6 & 4 & 3 & 4 \\
\hline & & performance & 5 & 4 & 3 & 5 & 4 & 4 & 4 & 4 & 4 & 4 & 4 & 7 & 7 & 6 \\
\hline \multirow{2}{*}{$\mathrm{E}$} & \multirow{2}{*}{ Team Structure } & importance & 7 & 4 & 7 & 4 & 5 & 6 & 6 & 5 & 3 & 5 & 5 & 7 & 4 & 5 \\
\hline & & performance & 3 & 4 & 4 & 2 & 2 & 3 & 3 & 3 & 3 & 5 & 1 & 3 & 3 & 6 \\
\hline \multirow{2}{*}{$\mathrm{F}$} & \multirow{2}{*}{ Culture } & importance & 5 & 6 & 3 & 3 & 4 & 1 & 2 & 3 & 2 & 3 & 5 & 4 & 4 & 2 \\
\hline & & performance & 2 & 6 & 5 & 3 & 5 & 1 & 1 & 4 & 2 & 3 & 2 & 4 & 1 & 3 \\
\hline \multirow{2}{*}{ G } & \multirow{2}{*}{ Human Resources } & importance & 3 & 4 & 7 & 6 & 3 & 6 & 6 & 7 & 6 & 1 & 2 & 7 & 3 & 6 \\
\hline & & performance & 2 & 3 & 3 & 4 & 5 & 3 & 2 & 3 & 1 & 4 & 4 & 3 & 3 & 2 \\
\hline
\end{tabular}

The third step: use the geometric mean and integrate all ideas of all experts. Here, $b_{j}$ is the final value of importance and $c_{j}$ is the final value of performance of the aspect $j$ that is the result of the cumulative idea of 14 experts.

$c_{j}=\left(\prod_{i=1}^{n} c_{j p}\right)^{1 / n} \quad$ and $\quad b_{j}=\left(\prod_{i=1}^{n} b_{j p}\right)^{1 / n}$ 


\section{Table 3}

The final values of importance and performance of the aspects

\begin{tabular}{cccc}
\hline Code & Aspect & ci & bi \\
\hline A & Project Management & 5.115 & 4.981 \\
B & System Management & 2.318 & 4.223 \\
C & Technological and Technical & 3.880 & 5.032 \\
D & Commercialization & 4.511 & 4.638 \\
E & Team Structure & 2.972 & 5.070 \\
F & Culture & 2.560 & 3.057 \\
G & Human Resources & 2.805 & 4.224 \\
\hline
\end{tabular}

The fourth step: calculate the threshold value with the arithmetic mean to determine the cells of IPA matrix.

$\mu_{b}=\frac{31,224}{7}=4,460$

$\mu_{c}=\frac{24,141}{7}=3,451$

The fifth step: the relative location of each of the qualitative aspects is determined on the IPA matrix.

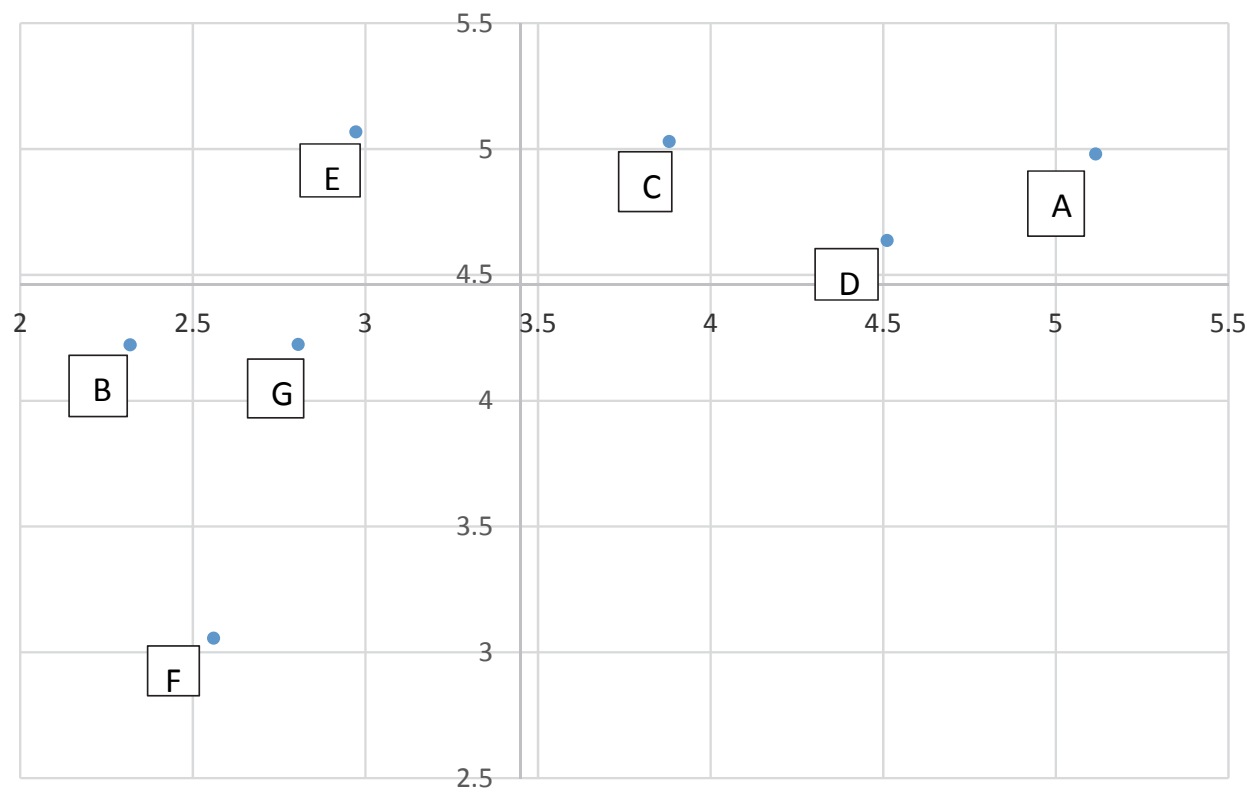

Fig. 3. Importance-performance analysis matrix of aspects

Three aspects A, C, and D are placed in the fourth quadrant (continue the good work). After the investigations are performed in the organization, it becames clear that these three aspects benefit from good strategies. For the same reason, these three aspects with the risk placeholder were selected as the inputs of the morphologic input. Currently, the mode of these three aspects in Saipa Company is as follows:

The project management aspect (A): management on the gates and deliveries of project (A4)

Technological technical aspect (C): the technique of modeling the today's products of the world's carmakers $(\mathrm{C} 1)$

The commercialization aspect (D): converting the customer's needs to the technical package (D1) 
Placeholder $(\mathrm{H})$ : risk $(\mathrm{H} 1)$

The sixth step: the weight of the aspect $\mathrm{j}$ is shown with $O W_{j}$ and it is calculated with $O W_{j}=\left|\left(b_{j}-c_{j}\right) \times b_{j}\right|$ In addition, it is normalized as $s w_{j}=\frac{o w_{j}}{\sum_{j=1}^{m} o w_{j}}$

Table 4

Weights and priorities of aspects

\begin{tabular}{ccccc}
\hline Code & Aspect & $o w_{i}$ & $s w_{i}$ & Priority \\
\hline A & Project Management & 0.669 & 0.020 & 6 \\
B & System Management & 8.042 & 0.242 & 2 \\
C & Technological and Technical & 5.797 & 0.174 & 4 \\
D & Commercialization & 0.591 & 0.018 & 7 \\
E & Team Structure & 10.634 & 0.320 & 1 \\
F & Culture & 1.520 & 0.046 & 5 \\
G & Human Resources & 5.995 & 0.180 & 3 \\
\hline
\end{tabular}

\section{Morphological Analysis}

The first step: determining the parameters and problem aspects

First, the known aspects from the literature were considered as the problem parameters.

The second step: determining the modes in each of the aspects of the problem status

In this step, several modes for each of the aspects of the morphologic status of the research were defined in discrete mode (based on the morphological analysis suppositions) regarding to the responses of the experts on the questionnaire and interview and screening these ideas by the guide of some university professors; they are fully shown in Table 5:

\section{Table 5}

The variables of morphological analysis of the research with their code

\begin{tabular}{|c|c|c|c|c|c|c|}
\hline Problem parameters & \multicolumn{6}{|c|}{ Decision options } \\
\hline Project management (A) & Quality (A1) & Time (A2) & Cost (A3) & Gate, Milestone ( & 44) & \\
\hline System management (B) & $\begin{array}{l}\text { Micro management } \\
\text { (B1) }\end{array}$ & Convincing (B2) & $\begin{array}{l}\text { Democratic } \\
\text { (B3) }\end{array}$ & $\begin{array}{l}\text { Consulting } \\
\text { (B4) }\end{array}$ & $\begin{array}{l}\text { Non-intervention } \\
\text { (B5) }\end{array}$ & \\
\hline $\begin{array}{l}\text { Technological, technical } \\
\text { (C) }\end{array}$ & $\begin{array}{c}\text { Modeling } \\
\text { Technique } \\
\text { (Benchmarking) } \\
\text { (C1) }\end{array}$ & $\begin{array}{c}\text { Reverse } \\
\text { engineering (C2) }\end{array}$ & $\begin{array}{l}\text { Platform } \\
\text { designing } \\
\text { (C3) }\end{array}$ & $\begin{array}{l}\text { Joint venture } \\
\text { (C4) }\end{array}$ & $\begin{array}{l}\text { Accurate and } \\
\text { complete defining } \\
\text { of the piece } \\
\text { features (C5) }\end{array}$ & $\begin{array}{l}\text { Cooperation of } \\
\text { piece producer } \\
\text { in designing the } \\
\text { product (C6) }\end{array}$ \\
\hline Commercialization (D) & $\begin{array}{l}\text { converting the } \\
\text { customer's needs to } \\
\text { the technical } \\
\text { package (D1) }\end{array}$ & $\begin{array}{l}\text { Using the need } \\
\text { assessment models } \\
\text { of the other } \\
\text { carmakers (D2) }\end{array}$ & $\begin{array}{l}\text { Changing the } \\
\text { market and } \\
\text { need (D3) }\end{array}$ & $\begin{array}{l}\text { Mixed } \\
\text { marketing } \\
\text { (D4) }\end{array}$ & & \\
\hline Team structure (E) & Matrix-Project (E1) & $\begin{array}{l}\text { Functional teams } \\
\text { (E2) }\end{array}$ & $\begin{array}{l}\text { Virtual team } \\
\text { (external pear } \\
\text { expert) (E3) }\end{array}$ & $\begin{array}{l}\text { Shamrock } \\
\text { (E4) }\end{array}$ & & \\
\hline Culture (F) & $\begin{array}{l}\text { Flexible and } \\
\text { dynamic (F1) }\end{array}$ & Structural (F2) & Risky (F3) & $\begin{array}{l}\text { Organizational } \\
\text { identity (F4) }\end{array}$ & $\begin{array}{c}\text { Reward for } \\
\text { innovation (F5) }\end{array}$ & \\
\hline Human resources $(\mathrm{G})$ & $\begin{array}{c}\text { Knowledge } \\
\text { management (G1) }\end{array}$ & $\begin{array}{c}\text { Social capital } \\
\text { management (G2) }\end{array}$ & $\begin{array}{l}\text { Career path } \mathrm{m} \\
\text { development })\end{array}$ & $\begin{array}{l}\text { agement(Personal } \\
\text { 3) }\end{array}$ & Empowerment ( & \\
\hline
\end{tabular}

Placeholder; the eighth aspect $(\mathrm{H})$

By adding an extra aspect to the known aspects from the literature of the research subject which is called the placeholder, two main ideas become accessible in the morphology method. The first is that the morphological model converts to a targeted status from the open and public status; and second is that, it will be possible to choose one of the placeholder modes and achieve the most compatible mode from the other aspects. The investigated different modes in placeholder of this study according to the will of experts are as follows: 
1. The mode with the least risk (Risk)

2. The mode with the appropriate performance speed while accuracy (Agile)

3. The mode with the least wastes (Lean)

The third step: forming the morphological field configuration

The number of binary relationships between parameters; here, if $\mathrm{N}$ equals to the number of parameters in a morphological field, then the number of blocks (components) of parameter in the cross consistency matrix filed (number of comparisons) is as following:

$\frac{1}{2} N(N-1)=\frac{1}{2}(8)(8-1)=28$

Identifying the simple configurations; to count the simple configurations, the below Formula is used.

$$
T_{S C}=\prod_{i=1}^{n} V_{i}
$$

Table 6

Counting the simple configurations

\begin{tabular}{cccc}
\hline Code & Aspect & Number of modes & Morphological field configurations \\
\hline A & Project management & 4 & The number of simple configurations \\
B & System management & 5 & $T_{S C}=\prod_{i=1}^{n} V_{i}$ \\
C & Technological, technical & 6 & \multirow{2}{*}{$4 * 5 * 6 * 4 * 4 * 5 * 4 * 3$} \\
D & Commercialization & 4 & $=115200$ \\
E & Team (structure) & 4 & \\
F & Culture & 5 & 4 \\
G & Human resources & 3 & \\
H & placeholder & & \\
\hline
\end{tabular}

As it can be observed from Table 4, the number of configurations of morphological field of the current study is 115000 combinations with eight members and they will be restricted by the cross consistency matrix.

The fourth step: cross consistency assessment matrix (CCM)

According to the formula, the number of comparisons must be done in the cross consistency assessment matrix is as follows:

$$
C_{t}=\sum_{i=1}^{n-1} \sum_{j=2}^{n} V_{i} \cdot V_{j}
$$

\section{Table 7}

Cross consistency assessment matrix

\begin{tabular}{cc}
\hline Cross consistency assessment matrix & $v_{i} \cdot v_{j}$ \\
\hline Number of cells of Cross consistency assessment matrix $(\mathrm{CCM})$ & $4^{*}(5)=20$ \\
$6^{*}(5+4)=54$ \\
$C_{t}=\sum_{i=1}^{n-1} \sum_{j=2}^{n} V_{i} \cdot V_{j}$ & $4 *(5+4+6)=60$ \\
$20+54+60+76+115+112+96=533$ & $5 *(5+4+6+4+4)=115$ \\
& $4^{*}(5+4+6+4+4+5)=112$ \\
\hline
\end{tabular}

After collecting the cross assessment questionnaires filled by " $\mathrm{x}$ " and "o" symbols, the integrated matrix of cross consistency assessment is determined like ISM method based on mode of comments. This integrated matrix represents 124 " $\mathrm{x}$ " type restrictions and 45 " $\mathrm{o}$ " type restrictions. After 
elimination of the configurations with " $x$ " type restriction, 140 configurations remained in the problem space. Then, with eliminating the configurations with "o" type restrictions, we reached four fully consistent configurations from 115200 configurations that can be observed in the tables $8,9,10$, and 11. It must be mentioned that this has been resulted from filling more than 30 million excel cells.

\section{Table 8}

The consistent configuration number 1 ; row 7466

\begin{tabular}{|c|c|c|c|c|c|c|c|}
\hline $\begin{array}{c}\mathrm{A} 4 \\
\text { Project } \\
\text { management }\end{array}$ & $\begin{array}{c}\mathrm{B} 2 \\
\text { System } \\
\text { management }\end{array}$ & $\begin{array}{c}\text { C5 } \\
\text { Technological, } \\
\text { technical }\end{array}$ & $\begin{array}{c}\text { D1 } \\
\text { Commercialization }\end{array}$ & $\begin{array}{c}\text { E4 } \\
\text { Team } \\
\text { (structure) }\end{array}$ & $\begin{array}{c}\text { F5 } \\
\text { Culture }\end{array}$ & $\begin{array}{c}\text { G1 } \\
\text { Human Resources }\end{array}$ & $\begin{array}{c}\mathrm{H} 3 \\
\text { Placeholder }\end{array}$ \\
\hline Quality & \multirow{2}{*}{$\begin{array}{c}\text { Micro } \\
\text { management }\end{array}$} & $\begin{array}{l}\text { Modeling Technique } \\
\text { (Benchmarking) }\end{array}$ & \multirow{2}{*}{$\begin{array}{l}\text { converting the customer's } \\
\text { needs to the technical } \\
\text { package }\end{array}$} & \multirow{2}{*}{ Matrix-Project } & Flexible and dynamic & Knowledge & \multirow[t]{2}{*}{ Risk } \\
\hline \multirow[b]{2}{*}{ Time } & & Reverse engineering & & & Structural & \multirow{2}{*}{ Social capital } & \\
\hline & Convincing & Platform design & \multirow{2}{*}{$\begin{array}{l}\text { Using the need assessment } \\
\text { models of the other } \\
\text { carmakers }\end{array}$} & $\begin{array}{c}\text { Functional } \\
\text { teams }\end{array}$ & Risky & & \multirow{2}{*}{ Agile } \\
\hline Cost & Democratic & Joint venture & & \multirow{2}{*}{$\begin{array}{l}\text { Virtual team } \\
\text { (external pear } \\
\text { expert) }\end{array}$} & $\begin{array}{l}\text { Organizational } \\
\text { identity }\end{array}$ & \multirow{2}{*}{$\begin{array}{l}\text { Career path } \\
\text { management } \\
\text { (Personal } \\
\text { development) }\end{array}$} & \\
\hline \multirow{2}{*}{ Gate (Milestone) } & Consulting & $\begin{array}{l}\text { Accurate and complete } \\
\text { defining of the piece } \\
\text { features }\end{array}$ & $\begin{array}{l}\text { Changing the market and } \\
\text { need }\end{array}$ & & \multirow{2}{*}{$\begin{array}{l}\text { Reward for } \\
\text { innovation }\end{array}$} & & \multirow{2}{*}{ lean } \\
\hline & Non-intervention & $\begin{array}{l}\text { Cooperation of piece } \\
\text { producer in designing } \\
\text { the product }\end{array}$ & Mix marketing & Shamrock & & Empowerment & \\
\hline
\end{tabular}

Table 9

Compatible configuration number 2, row 7858

\begin{tabular}{|c|c|c|c|c|c|c|c|}
\hline $\begin{array}{c}\mathrm{A} 2 \\
\text { Project } \\
\text { management }\end{array}$ & $\begin{array}{c}\text { B4 } \\
\text { System } \\
\text { management }\end{array}$ & $\begin{array}{c}\text { C6 } \\
\text { Technological, } \\
\text { technical }\end{array}$ & $\begin{array}{c}\text { D4 } \\
\text { Commercialization }\end{array}$ & $\begin{array}{c}\text { E4 } \\
\text { Team } \\
\text { (structure) }\end{array}$ & $\begin{array}{c}\text { F3 } \\
\text { Culture }\end{array}$ & $\begin{array}{c}\text { G4 } \\
\text { Human } \\
\text { Resources }\end{array}$ & $\begin{array}{c}\mathrm{H} 2 \\
\text { Placeholder }\end{array}$ \\
\hline Quality & \multirow[t]{2}{*}{ Micro management } & $\begin{array}{l}\text { Modeling Technique } \\
\text { (Benchmarking) }\end{array}$ & \multirow{2}{*}{$\begin{array}{l}\text { converting the customer's } \\
\text { needs to the technical } \\
\text { package }\end{array}$} & \multirow[t]{2}{*}{ Matrix-Project } & $\begin{array}{c}\text { Flexible and } \\
\text { dynamic }\end{array}$ & Knowledge & \multirow[t]{2}{*}{ Risk } \\
\hline \multirow[b]{2}{*}{ Time } & & Reverse engineering & & & Structural & \multirow[b]{2}{*}{ Social capital } & \\
\hline & Convincing & Platform design & \multirow{2}{*}{$\begin{array}{l}\text { Using the need assessment } \\
\text { models of the other } \\
\text { carmakers }\end{array}$} & $\begin{array}{c}\text { Functional } \\
\text { teams }\end{array}$ & Risky & & \multirow{2}{*}{ Agile } \\
\hline Cost & Democratic & Joint venture & & \multirow{2}{*}{$\begin{array}{l}\text { Virtual team } \\
\text { (external pear } \\
\text { expert) }\end{array}$} & $\begin{array}{l}\text { Organizational } \\
\text { identity }\end{array}$ & Career path & \\
\hline \multirow{2}{*}{ Gate (Milestone) } & Consulting & $\begin{array}{c}\text { Accurate and complete } \\
\text { defining of the piece } \\
\text { features }\end{array}$ & $\begin{array}{c}\text { Changing the market and } \\
\text { need }\end{array}$ & & \multirow{2}{*}{$\begin{array}{l}\text { Reward for } \\
\text { innovation }\end{array}$} & $\begin{array}{c}\text { (Personal } \\
\text { development) }\end{array}$ & \multirow{2}{*}{ lean } \\
\hline & Non-intervention & $\begin{array}{c}\text { Cooperation of piece } \\
\text { producer in designing } \\
\text { the product }\end{array}$ & Mix marketing & Shamrock & & Empowerment & \\
\hline
\end{tabular}

Table 10

Compatible configuration number 3, row 50534

\begin{tabular}{|c|c|c|c|c|c|c|c|}
\hline A4 & $\mathrm{B} 2$ & $\mathrm{C} 4$ & D2 & E4 & F1 & G1 & $\mathrm{H} 3$ \\
\hline $\begin{array}{c}\text { Project } \\
\text { management }\end{array}$ & $\begin{array}{c}\text { System } \\
\text { management }\end{array}$ & $\begin{array}{l}\text { Technological, } \\
\text { technical }\end{array}$ & Commercialization & $\begin{array}{c}\text { Team } \\
\text { (structure) }\end{array}$ & Culture & Human Resources & Placeholder \\
\hline Quality & \multirow{2}{*}{$\begin{array}{c}\text { Micro } \\
\text { management }\end{array}$} & $\begin{array}{c}\text { Modeling Technique } \\
\text { (Benchmarking) }\end{array}$ & \multirow{2}{*}{$\begin{array}{c}\text { converting the } \\
\text { customer's needs to the } \\
\text { technical package }\end{array}$} & \multirow{2}{*}{$\begin{array}{l}\text { Matrix- } \\
\text { Project }\end{array}$} & $\begin{array}{c}\text { Flexible and } \\
\text { dynamic }\end{array}$ & Knowledge & \multirow[t]{2}{*}{ Risk } \\
\hline \multirow[b]{2}{*}{ Time } & & Reverse engineering & & & Structural & \multirow[b]{2}{*}{ Social capital } & \\
\hline & Convincing & Platform design & \multirow{2}{*}{$\begin{array}{l}\text { Using the need } \\
\text { assessment models of } \\
\text { the other carmakers }\end{array}$} & $\begin{array}{c}\text { Functional } \\
\text { teams }\end{array}$ & Risky & & \multirow{2}{*}{ Agile } \\
\hline Cost & Democratic & Joint venture & & \multirow{2}{*}{$\begin{array}{c}\text { Virtual team } \\
\text { (external pear } \\
\text { expert) }\end{array}$} & $\begin{array}{c}\text { Organizational } \\
\text { identity }\end{array}$ & \multirow{2}{*}{$\begin{array}{l}\text { Career path } \\
\text { management } \\
\text { (Personal } \\
\text { development) }\end{array}$} & \\
\hline \multirow{2}{*}{$\begin{array}{c}\text { Gate } \\
\text { (Milestone) }\end{array}$} & Consulting & $\begin{array}{c}\text { Accurate and } \\
\text { complete defining of } \\
\text { the piece features }\end{array}$ & $\begin{array}{l}\text { Changing the market } \\
\text { and need }\end{array}$ & & \multirow{2}{*}{$\begin{array}{l}\text { Reward for } \\
\text { innovation }\end{array}$} & & \multirow[b]{2}{*}{ lean } \\
\hline & $\begin{array}{l}\text { Non- } \\
\text { intervention }\end{array}$ & $\begin{array}{c}\text { Cooperation of piece } \\
\text { producer in } \\
\text { designing the } \\
\text { product }\end{array}$ & Mix marketing & Shamrock & & Empowerment & \\
\hline
\end{tabular}




\section{Table 11}

Compatible configuration number 4, row 55921

\begin{tabular}{|c|c|c|c|c|c|c|c|}
\hline $\begin{array}{c}\text { A3 } \\
\text { Project } \\
\text { management }\end{array}$ & $\begin{array}{c}\text { B2 } \\
\text { System } \\
\text { management }\end{array}$ & $\begin{array}{c}\text { C6 } \\
\text { Technological, } \\
\text { technical }\end{array}$ & $\begin{array}{c}\text { D4 } \\
\text { Commercialization }\end{array}$ & $\begin{array}{c}\text { E4 } \\
\text { Team } \\
\text { (structure) } \\
\end{array}$ & $\begin{array}{l}\text { F5 } \\
\text { Culture }\end{array}$ & $\begin{array}{c}\text { G4 } \\
\text { Human } \\
\text { Resources } \\
\end{array}$ & $\begin{array}{c}\mathrm{H} 3 \\
\text { Placeholder }\end{array}$ \\
\hline Quality & \multirow{2}{*}{$\begin{array}{c}\text { Micro } \\
\text { management }\end{array}$} & $\begin{array}{c}\text { Modeling } \\
\text { Technique } \\
\text { (Benchmarking) } \\
\end{array}$ & \multirow{2}{*}{$\begin{array}{l}\text { converting the } \\
\text { customer's needs to the } \\
\text { technical package }\end{array}$} & \multirow{2}{*}{$\begin{array}{l}\text { Matrix- } \\
\text { Project }\end{array}$} & $\begin{array}{l}\text { Flexible and } \\
\text { dynamic }\end{array}$ & Knowledge & \multirow[t]{2}{*}{ Risk } \\
\hline \multirow{2}{*}{ Time } & & $\begin{array}{c}\text { Reverse } \\
\text { engineering }\end{array}$ & & & Structural & \multirow{2}{*}{ Social capital } & \\
\hline & Convincing & Platform design & \multirow{2}{*}{$\begin{array}{l}\text { Using the need } \\
\text { assessment models of } \\
\text { the other carmakers }\end{array}$} & $\begin{array}{l}\text { Functional } \\
\text { teams }\end{array}$ & Risky & & \multirow{2}{*}{ Agile } \\
\hline Cost & Democratic & Joint venture & & \multirow{2}{*}{$\begin{array}{c}\text { Virtual team } \\
\text { (external pear } \\
\text { expert) }\end{array}$} & $\begin{array}{c}\text { Organizational } \\
\text { identity }\end{array}$ & \multirow{2}{*}{$\begin{array}{c}\text { Career path } \\
\text { management } \\
\text { (Personal } \\
\text { development) }\end{array}$} & \\
\hline \multirow{2}{*}{ Gate (Milestone) } & Consulting & $\begin{array}{l}\text { Accurate and } \\
\text { complete defining } \\
\text { of the piece } \\
\text { features }\end{array}$ & $\begin{array}{l}\text { Changing the market } \\
\text { and need }\end{array}$ & & \multirow{2}{*}{$\begin{array}{l}\text { Reward for } \\
\text { innovation }\end{array}$} & & \multirow{2}{*}{ lean } \\
\hline & $\begin{array}{l}\text { Non- } \\
\text { intervention }\end{array}$ & $\begin{array}{l}\text { Cooperation of } \\
\text { piece producer in } \\
\text { designing the } \\
\text { product }\end{array}$ & Mix marketing & Shamrock & & Empowerment & \\
\hline
\end{tabular}

\section{Using the results obtained from IPA in GMA analysis}

By using the result of IPA analysis in identifying aspects with simultaneous good performance and importance, the current organizational modes were selected as following and added to the morphologic model.

Project management aspect (A): managing the gates and project's deliveries (A4);

Technological technical aspect (C): technique of modeling from the today's products of the world's carmakers $(\mathrm{C} 1)$;

Commercialization aspect (D): mixed marketing (D1);

Placeholder (H): Risk (H1);

The black cells represent the inputs of morphological model and the gray cells represent the obtained results.

Table 12

Configuration compatible with the IPA model's output, row 107317

\begin{tabular}{|c|c|c|c|c|c|c|c|}
\hline A4 & B3 & $\mathrm{C} 1$ & D4 & E4 & F5 & G1 & $\mathrm{H} 3$ \\
\hline $\begin{array}{c}\text { Project } \\
\text { management }\end{array}$ & $\begin{array}{c}\text { System } \\
\text { management }\end{array}$ & $\begin{array}{l}\text { Technological, } \\
\text { technical }\end{array}$ & Commercialization & $\begin{array}{c}\text { Team } \\
\text { (structure) }\end{array}$ & Culture & $\begin{array}{c}\text { Human } \\
\text { Resources }\end{array}$ & Placeholder \\
\hline Quality & \multirow{2}{*}{$\begin{array}{c}\text { Micro } \\
\text { management }\end{array}$} & $\begin{array}{c}\text { Modeling } \\
\text { Technique } \\
\text { (Benchmarking) }\end{array}$ & \multirow{2}{*}{$\begin{array}{l}\text { converting the } \\
\text { customer's needs to the } \\
\text { technical package }\end{array}$} & \multirow{2}{*}{$\begin{array}{l}\text { Matrix- } \\
\text { Project }\end{array}$} & $\begin{array}{l}\text { Flexible and } \\
\text { dynamic }\end{array}$ & Knowledge & Risk \\
\hline \multirow{2}{*}{ Time } & & $\begin{array}{c}\text { Reverse } \\
\text { engineering }\end{array}$ & & & Structural & \multirow{2}{*}{ Social capital } & \\
\hline & Convincing & Platform design & \multirow[b]{2}{*}{$\begin{array}{l}\text { Using the need } \\
\text { assessment models of } \\
\text { the other carmakers }\end{array}$} & $\begin{array}{c}\text { Functional } \\
\text { teams }\end{array}$ & Risky & & \\
\hline Cost & Democratic & Joint venture & & $\begin{array}{l}\text { Virtual team } \\
\text { (external pear }\end{array}$ & $\begin{array}{l}\text { Organizational } \\
\text { identity }\end{array}$ & \multirow{2}{*}{$\begin{array}{c}\text { Career path } \\
\text { management } \\
\text { (Personal } \\
\text { development) }\end{array}$} & Agile \\
\hline \multirow{2}{*}{ Gate (Milestone) } & Consulting & $\begin{array}{l}\text { Accurate and } \\
\text { complete defining } \\
\text { of the piece } \\
\text { features }\end{array}$ & $\begin{array}{l}\text { Changing the market } \\
\text { and need }\end{array}$ & expert) & \multirow{2}{*}{$\begin{array}{l}\text { Reward for } \\
\text { innovation }\end{array}$} & & \multirow{2}{*}{ lean } \\
\hline & $\begin{array}{l}\text { Non- } \\
\text { intervention }\end{array}$ & $\begin{array}{l}\text { Cooperation of } \\
\text { piece producer in } \\
\text { designing the } \\
\text { product }\end{array}$ & Mix marketing & Shamrock & & Empowerment & \\
\hline
\end{tabular}




\section{Conclusion}

The results obtained from this study will significantly contribute to the senior organizational decision makers in the field of the multiple aspects of the new product development problem. Due to the lack of public access to MA/Carma software, we can observe a few papers with morphological analysis in the world. In this study, we have tried to provide a domestic solution to solve the morphologic model and develop the morphological analysis method through an innovative method in Microsoft Excel software environment. The frequent variables such as management and control of the new product project, management ruling the organization, the type of the used technology and function method, commercialization of the developed products, the structure of the product development teams, the dominant and contextual culture of the organization, the treatment and the human resources management in order to maintain the quality were from the qualitative known variables in this study.

After determining the situation of each of the aspects in the four parts IPA matrix, three aspects were placed in the second quadrant (continue the work well). After the required investigations and determining the mode situation of these three aspects in Saipa Company, three modes of the project management in gates, using modeling technique in the technical aspect, and converting the customer will to the technical packages and product manufacturing in commercialization aspect were considered as the input of morphological model; and selecting the risk placeholder by the experts in investigations represented that the most consistent possible mode was in row 107,317 with four outputs of democratic senior management, shamrock team structure, the culture of reward for innovation, and knowledge management in the human resources aspect.

The notable point in the results of this research is that in the team (structure) aspect, all fully consistent configurations have the mode (option) E4, i.e. "shamrock" structure. Shamrock is the national symbol of Ireland and a small plant with three leaves on each of its shoots. In the early 1990s, Charles Hindi predicted that the future organizations would be shamrock organizations. These organizations would be more virtual organizations instead of having physical aspects; and determined the non-strategic activities in the value chain and assigned them to the external units. With this method, the costs of the organization would decrease and the management power would be spent in the fundamental activities. The structure of the shamrock organization is fully different from the traditional organizations. The number of management layers in the shamrock organizations would decrease and the management would be more a professional activity instead of being the symbol of a luxury and high-class level in the organization.

In terms of adopting with the theory of Hindi, it can be claimed that the prediction done on the shamrock structure is very flexible and functionally consistent with different configurations. Of course, to prove this theory, we will require a comprehensive research. The researcher recommends that the organizations that are more knowledge-based in terms of their work study and examine this plan in trial in order to complete their human resources needs. So that, the benefits and disadvantages of the shamrock organization will be comprehensively observed and it can give the human resources section a guide map.

The researcher recommends the managers of the profession-based systems requiring high innovation and creativity not to use the magnifying and democratic management methods. On one hand, the basic conflicts in the profession-based system with the need of an accurate and magnifying managerial look, and on the other hand, the creativity requirements with unlimited need of aesthetic and artistic mode are from the largest conflicts in the new product development. In the four selected patterns in this study, it was shown that the micro management is severely in conflict with the nature of the new product development. On the other hand, regarding to the fact that the democratic management emphasizes on the equality of votes and consensus on decision, it may only satisfy the innovation sense, fail in professionalism and its principled visions, and develop an attractive but unpractical and inefficient product. 
In addition, this study indicated that the purity of the process of new product development could be considered as a strategy and a key success factor in this field. The researches recommend to the studied organizations and the other industrial organizations of the country that along with all activities leading to the product development, it is better to pay attention to decrease in wastes (including time, cost, tiredness of workforce, working repeatedly, etc.) with the aim of purity and continuous quality of the process.

It is suggested that the other researchers of the operational research develop the field of morphological analysis through integrating the multi-criteria decision making methods and the general morphological analysis like DEMATEL, TOPSIS, ANP, etc. Since the morphological method has been hardly ever used in the international scientific papers, development, integration, and extending this method can create a unique chance for the operational research participants.

\section{References}

Abbey, A., \& Dickson, J. W. (1983). R\&D work climate and innovation in semiconductors. Academy of Management Journal, 26(2), 362-368.

Ali Ahmadi, A.R., Fekri, R., \& Fathian, M. (2009). Determining the Factors Influencing Agility of the Process of New Product Development through Using the Basic Components Analysis Approach (Case Study: Iranian Manufacturing Industries). Tomorrow Management, 17(21), 34-43.

Ardakani, S., Talei Far, R., Hatami Nasab, S.H., \& Mohammadi, F. (2011). Investigating and Ranking the Factors and Components Influencing the Process of New Product Development (the Study of SMEs Managers located in the Food and Drink Industry of Fars Province), Modern Marketing Research, 1(1), 101-126

Azar, A., Khosravani, F., \& Jalali, R. (2013). Soft Operational Research (Problem Structuring Approaches). Tehran: Industrial Management Organization, the first edition.

Chen, Y. (2012). The empirical analysis model on critical success factors for emergency management engineering information system. Systems Engineering Procedia, 5, 234-239.

Cooper, R. G. (1999). The invisible success factors in product innovation. Journal of product Innovation Management, 16(2), 115-133.

Cooper, R. G., \& Kleinschmidt, E. J. (2007). Winning businesses in product development: The critical success factors. Research-Technology Management, 50(3), 52-66.

Fritz, M., \& Schiefer, G. (2008). Food chain management for sustainable food system development: a European research agenda. Agribusiness, 24(4), 440-452.

Im, K., \& Cho, H. (2013). A systematic approach for developing a new business model using morphological analysis and integrated fuzzy approach. Expert Systems with Applications, 40(11), 4463-4477.

Jafari Khanshir, S., Radfar, R., Hosnavi, R., \& Azar Afzar, R. (2012). Identifying and prioritizing the key factors of success of new product development with the fuzzy induction approach, Quarterly of Industrial Management of Human Sciences University, Islamic Azad University of Sanandaj, 7(21), 67-81

Jantunen, A. (2005). Knowledge-processing capabilities and innovative performance: an empirical study. European Journal of Innovation Management, 8(3), 336-349

Kan'ani, A., \& Meygoun Pouri, M.R. (2014). Identifying and ranking the factors influencing the process of Systematic Technology in New Product Development in the Entrepreneur Active Companies in the Food Biotechnology Field. Quarterly of Entrepreneurship Development, 7(2), 487-507.

Kandemir, D., Calantone, R., \& Garcia, R. (2006). An exploration of organizational factors in new product development success. Journal of Business \& Industrial Marketing, 21(5), 300-310.

Khasm Afkan Nezam, M.H., Atafar, A., Nasr Esfahani, A., \& Shahin, A. (2014), Intellectual capital, the capability of organizational learning and effectiveness of the performance of new product development in car industry. Public Management Studies, 7(25), 57-74. 
Kotler (2004). Marketing Management: Analysis, Planning, Implementation \& Control. $11^{\text {th }}$ Ed. Englewood Cliffs: Prentice-Hall.

Kotler, P. (2005). Kotler on marketing. Simon and Schuster.

Lagrosen, S. (2005). Customer involvement in new product development: A relationship marketing perspective. European Journal of Innovation Management, 8(4), 424-436.

Lester, D. H. (1998). Critical success factors for new product development. Research-Technology Management, 41(1), 36-43.

Maidique, M. A., \& Zirger, B. J. (1984). A study of success and failure in product innovation: the case of the US electronics industry. IEEE Transactions on Engineering Management, (4), 192-203.

Matzler, K., \& Hinterhuber, H. H. (1998). How to make product development projects more successful by integrating Kano's model of customer satisfaction into quality function deployment. Technovation, 18(1), 25-38.

Meygoun Pouri, M.R.; Moshtaq Deylami, A.; Ebrahimi, S.M. (2014), Management of the New Product Design and Development, Tehran: Amir Kabir University Jahad Daneshgahi publications, the first Ed.

Mu, J., Peng, G., \& Tan, Y. (2007). New product development in Chinese SMEs: Key success factors from a managerial perspective. International Journal of Emerging Markets, 2(2), 123-143.

Naranjo Valencia, J. C., Sanz Valle, R., \& Jiménez Jiménez, D. (2010). Organizational culture as determinant of product innovation. European Journal of Innovation Management, 13(4), 466-480.

Poolton, J., \& Barclay, I. (1998). New product development from past research to future applications. Industrial Marketing Management, 27(3), 197-212.

Rafiei Nezhad, D. (2014), Innovation and Product Development and Commercialization, Translated by Mohammad Reza Meygoun Pouri Mohammad Mahdi Basir Pour, Tehran: Amir Kabir University Jahad Daneshgahi publications, the first Ed.

Rajab Zadeh Qotri, A.; Moezzi, F. (2014), New Product Development Models, Tehran: Saffar publication, the first Ed.

Ritchey, T. (1998). General morphological analysis. In 16th euro conference on operational analysis.

Ritchey, T. (2011). Wicked problems-social messes: Decision support modelling with morphological analysis (Vol. 17). Springer Science \& Business Media.

Sarmad Saeidi, S.; Mamqani, A.R. (2009), Identifying and Ranking the Key Factors Influencing the New Product Development in Saipa Automotive Group with AHP Technique, Journal of Industrial Managemnet Studies, 4(20), 167-194.

Seyed Hoseyni, S.M.; Iranban, S.J. (2004), The New Product Development Strategy, Approaches and Findings, Journal of Management Knowledge, 12(64), 81-105.

Sharma, B. N. (2007). Determinants of New Consumer Product Success or Failure in Nepal. Journal of Nepalese Business Studies, 3(1), 70-77.

Smith, A., Sparks, L., Hart, S., \& Tzokas, N. (2004). Delivering customer loyalty schemes in retailing: exploring the employee dimension. International Journal of Retail \& Distribution Management, 32(4), 190-204.

Talebi, K.; Salimi Torkamani, M.; Zare, H. (2011), Identifying and Ranking the Fundamental Success Factors in New Product Development in Small and Medium Businesses in Science and Technology Parks of Tehran, Quarterly of Modern Economy and Commerce, 19(2), 83-100.

Thompson, J. D. (2003). Organizations in action: Social science bases of administrative theory. McGraw-Hill, New York.

Tushman, M. L. (2007). Special boundary roles in the innovation process. Administrative Science Quarterly, 587-605.

Yoon, B., \& Park, Y. (2005). A systematic approach for identifying technology opportunities: Keyword-based morphology analysis. Technological Forecasting and Social Change, 72(2), 145160. 
(C) 2017 by the authors; licensee Growing Science, Canada. This is an open access article distributed under the terms and conditions of the Creative Commons Attribution (CC-BY) license (http://creativecommons.org/licenses/by/4.0/). 